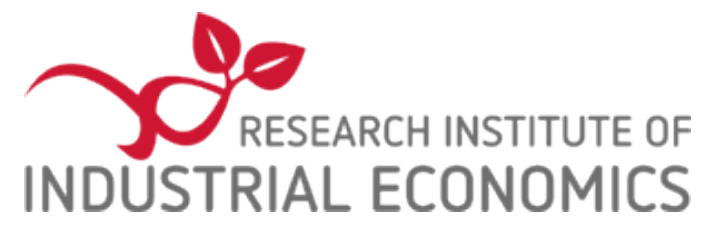

IFN Working Paper No. 1062, 2015

\title{
Are High-Growth Firms Overrepresented in High-Tech Industries?
}

Sven-Olov Daunfeldt, Niklas Elert and Dan Johansson 


\title{
Are High-Growth Firms Overrepresented in High- Tech Industries?
}

\author{
Sven-Olov Daunfeldt ${ }^{*}$, Niklas Elert ${ }^{* *}$, Dan Johansson* \\ *HUI Research, Regeringsgatan 60, SE-103 29 Stockholm, Sweden. \\ ** Corresponding author: niklas.elert@ifn.se, Research Institute of Industrial Economics \\ (IFN), Box 55665, SE-102 15, Stockholm, Sweden.
}

\begin{abstract}
It is frequently argued that policymakers should target high-tech firms, i.e., firms with high $R \& D$ intensity, because such firms are considered more innovative and therefore potential fast-growers. This argument relies on the assumption that the association among high-tech status, innovativeness and growth is actually positive. We examine this assumption by studying the industry distribution of high-growth firms (HGFs) across all 4-digit NACE industries, using data covering all limited liability firms in Sweden during the period 1997-2008. The results of fractional logit regressions indicate that industries with high $R \& D$ intensity, ceteris paribus, can be expected to have a lower share of HGFs than can industries with lower R\&D intensity. The findings cast doubt on the wisdom of targeting $R \& D$ industries or subsidizing $R \& D$ to promote firm growth. In contrast, we find that HGFs are overrepresented in knowledge-intensive service industries, i.e., service industries with a high share of human capital.
\end{abstract}

Keywords: Entrepreneurship; Firm growth; Gazelles; High-growth firms; High-impact firms; Innovation; R\&D

JEL-codes: L11; L25

\section{Acknowledgments}

We would like to thank Daniel Halvarsson, Johan Klaesson and Erik Stam for their comments and suggestions on a previous version. Research funding from the R\&D Fund of the Swedish Tourism and Hospitality Industry (BFUF) and the Jan Wallander and Tom Hedelius Foundation is gratefully acknowledged. 


\section{Introduction}

Most firms grow slowly or not at all, while a small number of highgrowth firms (HGFs) are major drivers of net job creation and economic growth (Birch and Medoff 1994; Storey 1994; Henrekson and Johansson 2010; Hölzl 2010; Coad et al. 2014a). HGFs have therefore received increasing attention from policymakers and researchers in recent years.

The European Commission (2010) mentions support for high-growth SMEs as a political objective in its Europe 2020 strategy, highlighting the share of fast-growing, innovative firms as a key indicator to measure the strategy's progress. Researchers also argue that policymakers should cease supporting start-ups and instead focus on the more promising potential entrepreneurs (Vivarelli 2013: 1479).

For example, Shane (2009) states that because most start-ups have no growth ambitions and a large majority of them will not survive, policy should instead target HGFs. However, as Mason and Brown (2013) note, the only practical policy advice Shane provides on how to achieve this object is to extend existing schemes that provide financial incentives for small firms to undertake R\&D, e.g., R\&D tax credits. Furthermore, the more general concern that firms may be underinvesting in $R \& D$ has resulted in government policies such as favorable fiscal treatment and R\&D subsidies (Coad and Rao 2010). ${ }^{1}$ OECD (2010), for example, reports that most policy initiatives implemented across its member countries rely on facilitating access to finance and support for R\&D and innovation.

Many policies for promoting growth in general and among HGFs in particular are, in other words, strongly biased towards high-technology sectors, typically defined as industries with a high degree of $\mathrm{R} \& \mathrm{D}$ intensity (Eurostat 2012; see also Schneider and Veugelers 2010; Coad et al. 2014a). As noted by Mason and Brown (2013: 214), "this clearly indicates that policy-makers view high-technology sectors as the main generators of potential HGFs". Whether HGFs have a higher presence in high-tech industries is thus important from a public policy perspective.

Nonetheless, it has been noted that HGFs are not necessarily synonymous with high-tech firms (Brännback et al. 2010), and at present, there is little evidence that HGFs are more common in such industries. Rather, a number of studies, addressing different countries and time periods, suggest that HGFs exist in most industries and are not overrepresented in

${ }^{1}$ Coad and Reid (2012: 10) argue that reasons of capability development and the possible existence of a job 'multiplier' effect in the high-tech sector (e.g. Moretti 2010; Moretti and Thulin 2012), makes high tech HGFs especially desirable from the point of view of policy makers. 
high-technology sectors (Henrekson and Johansson 2010).

As Bleda et al. (2013: 115) note, "there is little evidence that the [hightech] sector has a large impact on the emergence of gazelles”. For example, HGFs are nearly equally present in high-tech and low-tech sectors in the UK (Nesta 2009), where only approximately 15 percent of HGFs operate in high-tech sectors. Furthermore, these firms do not necessarily have extensive $R \& D$ or patent activity (Mason and Brown 2012). If anything, when considering a variety of countries, there appear to be more HGFs in service industries relative to other sectors such as manufacturing (Henrekson and Johansson 2010).

In the words of Buss (2002: 18), "policy makers chase high-tech firms as a priority when other sectors might pose better opportunities". For this reason, Mason and Brown (2013) argue that government policies to promote HGFs focus too narrowly on high-technology industries and should be re-directed to also include other industries (see also Brown et al. 2014).

Their advice is however based on studies that generally consider a limited number of industries, apply restrictive firm size thresholds, and use a high level of industry aggregation. Thus, the question of whether HGFs are overrepresented in high-technology industries - or elsewhere - has yet to be satisfactory answered.

In this paper, we argue that on the basis of what is generally known about the tails of the firm growth rate distribution, where HGFs reside, there is little reason to believe that there should be a positive association between $\mathrm{R} \& \mathrm{D}$ intensity and growth. In fact, previous evidence suggests that the crucial factor that seems to explain the prevalence of fat tails in the growth rate distribution is not $R \& D$, but rather some measure of human capital, e.g., special skills and training (Rossi-Hansberg and Wright 2007; Klette and Kortum 2004).

The purpose of this paper is to examine this question empirically by testing three hypotheses concerning the industry distribution of HGFs. The first two hypotheses are formulated to assess the conventional wisdom that HGFs are overrepresented in R\&D-intensive or high-tech industries. The third hypothesis stipulates that HGFs are more prevalent in service industries with a high level of human capital, a question that has been to some extent overlooked in the previous HGF literature.

Using a fractional logit model suitable for proportions that can take limiting values, we test these hypotheses using a data set that represents all limited liability firms in Sweden during the period 1997-2008. We 
define HGFs as the one percent of firms in the economy that experienced the fastest (absolute or relative) employment or sales growth during a 3year period and use the share of HGFs in industries at the 4-digit NACElevel as the dependent variable.

Concerning the first hypothesis, we find little evidence that higher industry R\&D intensity is associated with a greater share of HGFs, regardless of how HGFs are defined. Instead, higher R\&D intensity typically implies a smaller share of HGFs in the industry considered. The results are more ambiguous when considering industries defined as hightech (i.e., R\&D-intensive) manufacturing industries by Eurostat because the effect can go both ways, and it is difficult to observe any consistent pattern. These findings challenge the prevailing view among policymakers that high-tech or R\&D-intensive industries are beneficial for the emergence of HGFs. In contrast, we find some support for our third hypothesis, in that service industries characterized by a high share of tertiary educated workers are likely to experience a greater share of HGFs than the average industry. This suggests that further research should shine a light on the importance for human capital in fostering HGFs.

All results remain qualitatively similar when we perform regressions at the 3- and 5-digit NACE-levels, distinguish between organic and acquired growth, and only consider industries with at least 30 or 100 employees, as robustness checks. .

The remainder of the paper is organized as follows: A theoretical background on the relationship between innovation activities and firm growth is presented in Section 2, together with an overview of previous studies on the industry distribution of HGFs, before we formulate our hypotheses. Data and descriptive statistics regarding the industry distribution of HGFs are described in Section 3, while the econometric model is presented in Section 4 and the results in Section 5. Concluding remarks are provided in Section 6.

\section{Innovation activities, firm growth, and HGFs}

The Austrian economist Joseph Schumpeter (1934, 1943) ascribed economic growth to creative destruction - the process of transformation that accompanies innovation, caused by the discovery and use of novel ideas. From a Schumpeterian perspective, the innovations introduced by firms represent new knowledge, the economic value of which is not known with perfect certainty. Innovations can therefore be considered business experiments subject to a market test. In the market, firms are established to exploit and commercialize these ideas. But what firms? 
Schumpeter gave several answers to the question during his academic career.

The early "Mark I" Schumpeter (1934) emphasized entrepreneurship and the role of new (small) ventures in introducing novel ideas into the economic system. Subsequently, "Mark II" Schumpeter (1943) would argue that innovation was a routinized process best performed by large (old) firms, which are able to reap the benefits of economies of scale in production and R\&D (Malerba and Orsenigo 1995). Associating innovation with high-tech sectors and $R \& D$ can hence be regarded as ascribing to "Mark II" Schumpeter's view of the world. As Audretsch et al. (2006) point out, innovative activities are usually seen as the result of systematic and purposeful efforts to create new knowledge by investing in R\&D, followed by commercialization (Griliches 1979; Chandler 1990; Cohen and Levinthal 1989; Warsh 2006).

The questions of which firms innovate and whether the same firms grow have caused a longstanding discussion (Davidsson et al. 2010). While "a propensity for innovation emerges in general as a firm's growth driver" according to Vivarelli (2013), others stress that the self-reinforcing dynamics in the economy may lead to a relatively weak association between the ability to innovate and actual performance, and even if firms are successful in innovation and benefit from it, it is not clear that they will grow (Kirchoff 1994; Geroski et al. 1997; Coad and Hölzl 2010; Denrell and Liu 2012; Coad et al. 2014b:8).

The Mark I - Mark II dichotomy can be related to the literature on 'technological regimes' pioneered by Winter (1984), which argues that the industry-specific technological regime has a major influence on firm competitiveness (Audretsch 1995). Audretsch and Thurik (2000) argue that in recent decades, highly developed economies experienced a general shift from a managed to an entrepreneurial economy, and van Stel et al. (2005) relate Mark I and II innovation to an 'entrepreneurial' and a 'managed' economy, respectively. While knowledge-driven innovation is frequently thought of as the outcome of R\&D-activities, a set of other means of innovation, such as learning-by-doing, networking and combinatorial insights, suggests a role for entrepreneurs (Braunerhjelm 2011). The production of new products or qualities can hence occur due to either R\&D investments by incumbents, or by entrepreneurial start-ups who combine knowledge in innovative ways without R\&D (Acs et al. 2009). ${ }^{2}$

\footnotetext{
${ }^{2}$ Related to these questions is also the $R \& D$ growth paradox, which suggests that there is a growing gap between R\&D expenditures and GDP over time, with R\&D efforts growing substantially faster. Ejermo et al (2011) investigate the Swedish economy
} 
If there has indeed been a shift towards Mark I innovation in recent decades, then this presents a conundrum for policymakers focusing on high-tech industry, as Mark I-innovation is not as readily associated with high-tech industries as Mark II-innovations. However, this shift is arguably a matter of degree, and many studies emphasize the complementary roles of firms of different sizes. While large, established firms succeed in traditional technological fields based on large R\&D activities, the function of new firms is to explore new technological areas. Small, entrepreneurial firms introduce many of the radically new innovations, 'revolutionary breakthroughs', while large firms are more risk-averse and provide 'cumulative incremental improvements', the combined effect of which should not be underestimated (Acs and Audretsch 2005). As Baumol (2004: 13) writes, “Of course, that initial invention was an indispensable necessity for all of the later improvements. However, it is only the combined work of the two together that made possible the powerful and inexpensive apparatus that serves us so effectively today".

Nonetheless, many theoretical models have associated R\&D with innovation and firm growth, thereby implicitly subscribing to a Mark II view of the world. ${ }^{3}$ For example, Pakes and Ericson (1998) describe firm growth as a process of "active learning", in a model in which firms maximize expected net cash flows and are aware of productivity distribution shocks (see also Hopenhayn 1992; Ericson and Pakes 1995). Contrary to Jovanovic's (1982) model of passive learning, Pakes and Ericson (1998) highlight the importance of learning by undertaking innovative activities, in that a firm must decide how much to invest in R\&D. Klette and Griliches (2000), however, construct a quality ladder model to incorporate firm growth and R\&D, such that firms compete to improve the quality of products through cumulative innovations by investing in $\mathrm{R} \& \mathrm{D}$, which is treated as a sunk cost.

1985-2001, and find that the paradox occurs only in fast-growing manufacturing and service sectors. Fast-growing sectors show an increasing gap between R\&D and valueadded growth, while the slow-growing sectors do not. They do not interpret this paradox as a sign of failure of the national innovation system, as the largest gap would then be for the slow-growing sectors, failing to transform R\&D to economic growth. Instead, they see the evidence as consistent with the idea of diminishing marginal returns to $R \& D$ investment in high-investing sectors, but point out that rendering the innovation system more effective could yield better outcomes.

3 This is also the case for endogenous growth models (c.f. Romer 1986, 1990; Lucas 1988; Rebelo 1991; Aghion and Howitt 1992; Segerstrom 1995) in which the importance of knowledge spillovers is emphasized. Such models predominantly regard the growth process as an $R \& D$ race in which a fraction of $R \& D$ translates into successful innovations. Thus, while "the new growth theory is a step forward in our understanding of the growth process, the essence of the Schumpeterian entrepreneur is missed" (Acs 2009: 328). Attempts to introduce Schumpeterian entrepreneurs, who innovate but are not involved in R\&D activities, have been made by, e.g., Acs et al. (2004, 2009) and Braunerhjelm et al. (2010). 
However, while a Mark II view of the word has theoretical traction, the empirical picture is far from clear-cut, which Coad and Rao (2008) consider a paradox. While many theoretical and descriptive contributions highlight the importance of innovation in firm growth, few studies observe a strong association between innovation and firm growth. This may be because converting $R \& D$ into innovation and innovation into growth takes time (Coad and Rao, 2008), an observation that is further complicated by the uncertainty inherent in any innovative process (Cefis and Orsenigo 2001; Coad and Rao 2010; Segarra and Teruel 2014).

There are also models that provide the opposite indication, at least with respect to R\&D and growth. Building on previous literature (cf. Pakes and Ericsson 1998; Klette and Griliches 2000), Klette and Kortum (2004: 1007) identify two opposing forces that should influence the empirical relationship between $R \& D$ and firm size. On the one hand, there are diminishing returns to additional R\&D investments. On the other hand, large firms have more knowledge resources that they can devote to $R \& D$ activities. The empirical evidence suggests that these two forces cancel one another out on average, making R\&D intensity (i.e., R\&D expenditures as a fraction of revenue) independent of firm size (see also Cohen and Klepper 1996).

This also entails that large firms have higher $R \& D$ expenditures. Moreover, it is well established that the standard deviation of firm growth is smaller for large firms than for small firms (Stanley et al. 1996). Because a higher standard deviation entails thicker tails, one would hence expect a negative relationship between $R \& D$-expenditures and the industry proportion of HGFs. Considering R\&D-intensity (expenditures/revenue) or controlling for industry size would then lead to a prediction of no relationship between $R \& D$ and firm growth, provided that the two forces cancel one another out. Thus, from the perspective of the firm growth rate distribution, the link between R\&D and high growth seems tenuous at best.

Therefore, it is perhaps not surprising that previous empirical studies on the industry distribution of HGFs paint a rather ambiguous picture. Early research found evidence of a link between technology and firm growth (Storey 1991, 1994; Kirchoff 1994), and a number of more recent studies have found indications of a positive association between high-tech status or R\&D intensity and HGFs (Schreyer 2000; Delmar et al. 2003; Hölzl 2009; Stam and Wennberg 2009). Schreyer (2000: 25), in a study covering six European countries, notes that "all the existing evidence points in the same direction: high-growth firms are more technology intensive than the average firm.” Hölzl (2009), moreover, finds that in 
countries closer to the technological frontier, HGFs have a higher R\&D intensity than non-HGFs. Further, in a least squares regression framework, Stam and Wennberg (2009) demonstrate that R\&D has a positive effect on growth for the top 10 percent of fastest growing startups, but this is not the case for the overall population of firms. In a study of Spanish firms, Segarra and Teruel (2014) find that R\&D investments positively affect the probability of becoming a HGF but the effect is greater and more often significant in manufacturing industries than in service industries.

Nevertheless, other studies report either an absence of or a negative link between high-tech status or R\&D and the presence of HGFs (Birch and Medoff 1994; Birch et al. 1995; Almus 2002; Acs et al. 2008; Wyrwich 2010; Nesta 2009). It has become something of a "stylized fact" (Henrekson and Johansson 2010) that HGFs can be found in all industries (Deschryvere 2008; Léopez-Garcia and Puente 2009; Anyadike-Danes et al. 2009; Nesta 2009; Mason and Brown 2012) and, if anything, are overrepresented in service sectors (Autio et al. 2000; Schreyer 2000; Halabisky et al. 2006).

Some studies furthermore indicate that HGFs are overrepresented in knowledge-intensive service industries, i.e., service sectors characterized by a high level of human capital (Delmar et al. 2003; Davidsson and Delmar 2006; Deschryvere 2008). While this is by no means a universal finding, it receives credence from the literature on the firm growth rate distribution. Notably, Rossi-Hansberg and Wright (2007) demonstrate that high growth rates and a higher standard deviation are related to the amount of human capital specific to the industry, e.g., special skills and training. These characteristics are also more present in service industries than in capital-intensive industries, which is consistent with the assessment of a possible overrepresentation of HGFs in service industries (Henrekson and Johansson 2010). Generally, the importance of education and human capital in fostering firm entry, survival and growth has been demonstrated in a number of studies (Bates 1990; Gimeno et al. 1997; Acs et al. 2007; Geroski et al. 2010; Colombo and Grilli 2010; Arivantis and Stucki 2012).

Granted, the ambiguity in the previous HGF literature is in part to be expected given the ever-changing nature of the economy. As Dosi (2007) argues, heterogeneity in degrees of innovativeness and production efficiencies and, hence, firm growth should be expected to be the outcome of idiosyncratic capabilities, mistake-ridden learning and forms of pathdependent adaptation. Nonetheless, it is possible to identify certain factors that may help explain the ambiguous findings reported in previous 
research.

First, as discussed above, conditions may differ across countries and over time, and studies address different countries and time periods, often cover only a limited number of industries, and apply size thresholds. Furthermore, because their industry distribution is only one of many aspects of the HGFs under examination, little space is generally devoted to this issue; however, in recent years, some studies (Almus, 2002; de Wit and Timmermans 2008; Hölzl 2009; Wyrwich 2010; Stam and Wennberg 2009; Segarra and Teruel 2014) employ econometric methods to examine it directly.

As demonstrated above, the Mark II definition of innovation is closely tied to $R \& D$. Indeed, while firms perform $R \& D$ activities with a variety of objectives in mind, most business $R \& D$ seeks to develop new and improved goods, services, and processes (NSF 2010: 18), activities that overlap with several of the categories that Schumpeter lists as instances of innovation (Schumpeter 1934: 66). Considering the previous empirical literature on the link between $R \& D$ and growth, however, lends little support to the notion that additional $R \& D$ would translate into higher growth rates.

Notably, the work of Klette and Kortum (2004) and Rossi-Hansberg and Wright (2007) may in part explain why the previous evidence on the industry distribution of HGFs is so ambiguous with respect to their presence in high-tech industries, and stands in stark contrast to the prevailing view among policymakers that the relationship between $R \& D$ intensity and high growth is a positive one.

In view of the importance of high-tech status as a tool that policymakers employ to identify HGFs, empirical studies that explicitly examine the association among high-tech status, innovation and HGFs are needed. This makes it relevant to formulate and test the two hypotheses regarding the relationship between industry $R \& D$ intensity and the industry distribution of HGFs. These hypotheses are hence formulated in view of their importance for policy and are not theory-driven.

Hypothesis 1: Ceteris paribus, HGFs will be more common in industries with greater $R \& D$ intensity.

If current policies targeting high-tech industry to promote high-growth firms are sound, then one would expect us to be unable to reject this hypothesis. In view of the previous literature concerning the link between $\mathrm{R} \& \mathrm{D}$ and growth, we however expect a non-existent relationship.

The second hypothesis is formulated with a particular definition of high- 
tech industries in mind, namely that espoused by OECD/Eurostat, which defines industries as high-tech manufacturing industries according to their global technological intensity ${ }^{4}$. Scrutinizing how this particular definition of high-tech industry relates to high growth is particularly important because it forms the foundation of policy. We therefore formulate the second hypothesis related to R\&D as follows:

Hypothesis 2: Ceteris paribus, HGFs will be more common in manufacturing industries with greater $R \& D$ intensity.

Again, if current policies targeting high-tech industries to promote highgrowth firms were sound, one would expect us to be unable to reject this hypothesis. In view of the previous literature concerning the link between $R \& D$ and growth, we would expect a non-existent relationship, or possibly even a negative one, because HGFs appear, if anything, to be overrepresented in service industries according to the previous literature (Henrekson and Johansson 2010).

This observation is also important for our third hypothesis, which is also informed by Rossi-Hansberg and Wright (2007), who demonstrate that high growth rates and standard deviations are related to the amount of human capital specific to the industry, e.g., special skills and training. Therefore, one would expect a positive link between industry human capital and the share of HGFs in that industry.

Because we lack access to any common measure of human capital in our database, we again turn to Eurostat, which defines knowledge-intensive service industries according to their share of tertiary workers. ${ }^{5}$ Arguably, it is important to determine whether this definition is sounder in identifying fast-growers. This leads us to formulate our third hypothesis:

Hypothesis 3: Ceteris paribus, HGFs will be more common in service industries with more human capital.

Previous findings regarding the slight overrepresentation of HGFs in service industries, in conjunction with the abovementioned link identified

\footnotetext{
${ }^{4}$ In the OECD International Standard Industrial Classification, technology intensity is measured through two main indicators: $R \& D$ divided by production and $R \& D$ divided by value added. In its own words: "The Secretariat experimented with various criteria to identify the technology content of an industry, but quantification was hampered by the absence of data. As a result, R\&D intensity became the sole criterion” (Hatzichronoglou 1997: 7). To create the categories high, medium high, medium low and low technology, the OECD estimates expenditures for 12 OECD countries (Sweden included) for the time period 1991-1999 (OECD 2005). The OECD classification has been stable since its inception. The industries that are defined as high-tech manufacturing according to NACE Rev. 2 are enumerated in Table A1 in the appendix.

${ }^{5}$ Eurostat bases its definition on the Frascati Manual, see OECD (2002) and Eurostat (2012: 12). The industries that are defined as knowledge-intensive services according to NACE Rev. 2 are enumerated in Table A1 in the appendix.
} 
between human capital and growth, leads to the expectation that we will be unable to reject this hypothesis.

\section{Data and descriptive statistics}

\subsection{Data and the dependent variable}

All limited liability firms in Sweden are required to submit annual reports to the Swedish Patent and Registration Office (PRV). The data used in this study are collected from PAR, a Swedish consulting firm that gathers economic information from PRV. Our data comprise all Swedish limited liability companies active at some point between 1997 and 2008, yielding a total of 164,808 firms and 1,401,684 firm-year observations. The data include all variables in the annual reports, e.g., profits, number of employees, salaries, fixed costs, and liquidity.

Because employment and sales are the two most common growth indicators in the HGF literature (Daunfeldt et al. 2014a), we use both of them to identify HGFs. We follow recent contributions (e.g., Daunfeldt et al. 2014a; Coad et al. 2014c; Daunfeldt and Halvarsson 2014) and define HGFs as the one percent of firms in the economy with the highest employment or sales growth over a three-year time period. ${ }^{6}$ Absolute measures of firm growth lead to a bias towards large firms, while relative growth measures lead to a bias towards small firms (c.f. Acs et al. 2008; Schreyer 2000). The use of both measures is nonetheless widespread, and we use both for each growth indicator. ${ }^{7}$

To summarize, we measure growth in two different ways and thus arrive at four groups of HGFs, which we label absolute employment-HGFs, relative employment-HGFs, absolute sales-HGFs, and relative salesHGFs. All four groups consist of the one percent of firms that exhibit the highest growth (under this combination of measurement and indicator) in the entire economy over a three-year period.

A limitation of most studies on HGFs is that they cannot distinguish

\footnotetext{
${ }^{6}$ A number of studies have also used the Eurostat-OECD definition of HGFs. This definition requires HGFs to have at least ten employees at the beginning of the year and annualized employment (or sales) growth exceeding 20 percent during a 3-year period. However, Daunfeldt et al. (2014b) have shown that this definition excluded 95 percent of all firms in the Swedish economy during the period 2005-2008 and approximately 40 percent of all jobs created. We therefore chose not to use this definition when identifying HGFs. We furthermore considered longer time periods and other shares of the firm population, such as the three or five percent of firms with the highest growth. The results are very similar to those reported in the paper and have been omitted to save space. These results are available from the authors upon request.

${ }^{7}$ While some studies have used the so-called Birch index, i.e., growth measured with a combination of absolute and relative numbers (Schreyer 2000; Lopez-Garcia and Puente 2009), Hölzl (2014) demonstrates that the Birch index primarily captures absolute employment changes. We therefore elect not to use the Birch index.
} 
organic from acquired growth, which means that firms can only be identified as HGFs because they have merged with another firm. Our data contain information on mergers and acquisitions, enabling us to distinguish between organic and acquired growth as a robustness check for our analysis.

To construct each dependent variable, we take the definitions of HGFs as our point of departure. Because we address four definitions of HGFs, we have four dependent variables to include in a regression framework. The four types of HGFs were defined as the one percent of firms that grew fastest in the economy as a whole. Our dependent variables are industry specific and defined as the share of HGFs in an industry i, i.e.,

$$
\mathrm{SHGFs}_{i}=\text { Number of HGFs } s_{i} / \text { Number of firms }{ }_{i .} \text {, }
$$

where SHGFsi is measured at the 4-digit NACE industry level in the main regressions presented in Tables 2 and 3. The results for defining the dependent variable at the 3- and 5-digit levels are reported in conjunction with other robustness checks in Table $4 .^{8}$

Table A1 in the appendix reports the industry distribution of HGFs at the 2-digit NACE-level. Because HGFs are defined as the fastest growing 1 percent of firms in the overall economy, it follows by definition that an industry has an overrepresentation/underrepresentation of HGFs if the share of HGFs in the industry is higher/lower than 1 percent. We follow the European Commission and Eurostat and classify NACE 2-digit industries as high-technology manufacturing according to R\&D intensity and as knowledge-intensive services according to the share of tertiary educated persons (Eurostat 2012).

In total, there are two manufacturing industries at the 2-digit NACE level that are classified as "high tech": (21) manufacturing and pharmaceuticals and (26) manufacturing of computer electronics and optical products. Both of these industries have, on average, an overrepresentation of all types of HGFs except relative sales-HGFs. It remains unclear whether this actually concerns their R\&D intensity or some other underlying

\footnotetext{
${ }^{8}$ Here we should point out that the modeling of the dependent variable as an industry share inevitably precludes using the firm as the level of analysis. Important in this respect is the contribution by Srholec and Verspogen (2012) who assess the heterogeneity of the innovation process. They find that while sectors and countries matter to a certain extent, more of the variance is given by heterogeneity among firms within both of them. However, they observe that groups of firms produced by cluster analysis account for much higher share of the variance, which indicates that the most relevant stratification of the data cuts across the established sectoral and national boundaries.
} 
characteristic. Regarding knowledge-intensive service industries, the view is fairly ambiguous, with some industries having an overrepresentation in HGFs and others having an underrepresentation. ${ }^{9}$

\subsection{Independent variables}

In our dataset, we have access to information on firms' $R \& D$ expenditures, i.e., the total amount spent on R\&D annually, which is believed to indicate the level of effort dedicated to producing future products and process improvements while maintaining the current market share and increasing operating efficiency (NSF 2010: 18-19). According to Swedish accounting law, such expenditures are to be written down each year by a "reasonable amount", but by no less than one-fifth unless under special circumstances. This assumes a depreciation rate of 20 percent for the $R \& D$ stock, a reasonable rate given the findings of Bernstein and Mamuneas (2006), who find that R\&D capital depreciates in approximately $3-5$ years. ${ }^{10}$

R\&D-intensity is a statistic that provides a means of gauging the relative importance of $R \& D$ across industries and among firms in the same industry (NSF 2010: 18-19). We compute it by taking the ratio of R\&D expenditures to sales. We proceed by using industry R\&D intensity to test hypothesis 1 in a first model specification. If the hypothesis holds, we expect to observe a positive coefficient for this variable.

We test hypotheses 2 and 3 in a second model specification. To test hypothesis 2, we use Eurostat's classification of high-tech industry, which is described in greater detail in section 3.2, as a measure of industry innovation activity, generating a dummy for high-tech manufacturing industries based on their R\&D intensity. To test hypothesis 3, we employ the dummy provided by Eurostat to assess (high-tech) knowledgeintensive service industries, based on a high share of tertiary educated persons. For hypotheses 2 and 3 to hold, the dummies should exhibit a

\footnotetext{
9 The high-tech manufacturing sectors are (21) Manufacturing of pharmaceuticals and (26) Manufacturing of computer, electronics and optical products. The knowledgeintensive service sectors are (59) Motion picture, video and television programme production, sound recording and music publishing activities, (60) Programming and broadcasting activities, (61) Telecommunications, (62) Computer programming, consultancy and related activities, (63) Information service activities, and (72) Scientific research and development.

${ }^{10} \mathrm{R} \& \mathrm{D}$ is a durable input, as its productive capacity lasts for more than one time period. Consequently, accounting for the productive contribution of R\&D should ideally involve an evaluation over several time periods. This nonetheless requires several assumptions, notably regarding the price of use and the price of ownership or purchase, where the price of ownership equals the discounted expected stream of future rental payments or user costs that the asset is expected to yield over time. Unobservability problems are inherent in all such calculations (cf. Jorgenson and Griliches 1967; Hulten 1990).
} 
positive association with the share of HGFs in an industry.

Turning to our control variables, a measure of industry firm size is included to control for the fact that large firms make greater $R \& D$ expenditures, while the standard deviation of firm growth is smaller for large firms than for small firms (Stanley et al. 1996). Furthermore, there is evidence that HGFs, regardless of definition, are on average younger than other firms (Daunfeldt et al. 2014a). A number of studies on firm growth argue that firm age is negatively associated with growth (Evans 1987; Dunne and Hughes 1999; Yasuda 2005; Calvo 2006; Haltiwanger et al. 2013), and a link may exist at the industry level. We therefore expect that firms in industries with older firms are less likely to exhibit rapid firm growth, due to a lower level of business opportunity (e.g., Coad 2007: 40). The median firm age and the standard deviation of firm age within the industry are also included to assess whether industries with younger firms are more likely to have a higher share of HGFs.

The size of an industry could also affect firm growth rates. For example, in the presence of geographic clustering, agglomerations within industries may create advantages in the form of spillovers and cooperation between firms (Krugman 1992; Aghion and Howitt 1992; Van Ort and Stam 2006). There may furthermore be a bias towards observing a larger share of HGFs in small industries, due to what can essentially be considered a regression to the mean effect; industries with fewer firms should be more sensitive to having a large share of HGFs. Proxies for industry size, measured as the total number of firms and total employment in the sector, are included to capture this effect.

We further include measures of industry entry and exit to capture industry turnover. Arguably, industries with more turnover can be expected to be more conducive to high growth and hence have more HGFs (Johansson 2005; Brown et al. 2006). In contrast, industries with a greater firm concentration can be argued to exhibit less high growth because a smaller number of market participants have a greater probability of overcoming collective action problems and collaborate to deter entry and small firm growth (Orr 1974; Chappell et al. 1990; Geroski 1995). We measure industry concentration using a Herfindahl index, which is computed as the sum of squares of firms' shares of industry revenue, i.e., $s_{1 j}{ }^{2}+s_{2 j}{ }^{2}+\ldots+$ $s_{k j}{ }^{2}$, where $k$ is the number of firms.

Descriptive statistics for all variables included in our study are presented in Table 1. All variables are defined at the 4-digit NACE level. The descriptive statistics depict a rather heterogeneous picture, particularly concerning the four dependent variables. While the mean industry share of HGFs (of any kind) ranges between 0.01 and 0.03 , the minimum share 
is 0 , and the maximum share is 1 for all types of HGFs, other than relative sales-HGFs, for which the highest share is 0.67 .

Table 1. Descriptive statistics for industry variables at the 4-digit NACE level, 2000-2008

\begin{tabular}{lrrrrr}
\hline \hline Variable & Mean & Median & Std. Dev. & Min & Max \\
\hline \hline Absolute employment-HGFs (share) & 0.02 & 0.00 & 0.07 & 0.00 & 1.00 \\
Relative employment-HGFs (share) & 0.01 & 0.00 & 0.04 & 0.00 & 1.00 \\
Absolute sales-HGFs (share) & 0.03 & 0.00 & 0.08 & 0.00 & 1.00 \\
Relative sales-HGFs (share) & 0.01 & 0.00 & 0.03 & 0.00 & 0.67 \\
R\&D expenditures (SEK) & 9,106 & 0.00 & 170,942 & 0.00 & $7,085,560$ \\
Revenue (SEK) & $4,480,548$ & 738,251 & $13,400,000$ & 45 & $261,000,000$ \\
R\&D intensity (\%) & 0.12 & 0.00 & 0.93 & 0.00 & 51.50 \\
Employees & 1,543 & 376 & 3,588 & 1 & 48,687 \\
Concentration (Herfindahl) & 0.330 & 0.382 & 0.266 & 0.00363 & 0.99999 \\
Mean age & 23.2 & 22.0 & 5.8 & 11.0 & 36.5 \\
Sd (age) & 6.5 & 6.836713 & 1.8 & 0.0 & 14.4 \\
Entry & 2.83 & 0.00 & 10.49 & 0.00 & 232 \\
Exit & 6.51 & 1.00 & 22.40 & 0.00 & 462 \\
Number of firms & 100.73 & 23.00 & 279.02 & 2.00 & 4,733 \\
\hline N & 7,355 & & & & \\
\hline \hline
\end{tabular}

This discrepancy across industries is in part driven by differences in industry size; the number of firms in an industry ranges between 2 and 4,733. As a consequence, in small industries, the presence of a few HGFs in a given year is sufficient to entail substantial overrepresentation. Nevertheless, the industry-year observations in which the share of HGFs is zero number in the thousands regardless of which definition of HGFs we consider, while very few industry-year observations actually exhibit a share as high as 1 . Because the shares of HGFs form our dependent variables, their characteristics need to be considered when selecting the appropriate regression model, most notably that they are proportions that can take the values 0 and 1 .

We also note large discrepancies in many independent variables. Notably, R\&D-intensity, employment, concentration, entry, and exit vary substantially across industries. This underscores the importance of including such variables in the regression framework.

\section{Empirical model}

As shown above, the share of HGFs in industry $\mathrm{i}$ is a proportion bounded between zero and one. This restriction on the dependent variable makes 
linear regression unattractive, as it may yield fitted values that exceed the lower and upper bounds. The effect of the explanatory variables also tends to be non-linear, and the variance decreases when the mean approaches one of the boundaries. One strategy for addressing this for response variables strictly within the unit interval is to employ a logit transformation:

$$
y_{i}=\frac{1}{1+\exp \left(-x_{i} \boldsymbol{\beta}\right)},
$$

thereby yielding the transformed response variable $y_{i}^{*}$,

$$
y_{i}^{*}=\log \left(\frac{y_{i}}{1-y_{i}}\right)=\boldsymbol{x}_{\boldsymbol{i}} \boldsymbol{\beta}+\varepsilon,
$$

where $\varepsilon$ is a stochastic error term. Linear regression can then be used to model the logit transformation $y_{i}^{*}$ as a linear function of a set of regressors $\boldsymbol{x}_{\boldsymbol{i}}$, where $\boldsymbol{\beta}$ is a set of unknown parameters. However, this requires that the values of the prediction lie within the unit interval. Neither zeroes nor ones can be included in the logit strategy because the above transformation is not defined for those values. Yet as noted in section 3.2, we consider dependent variables for which the limiting values of 0 and 1 are not only possible but abundant in the case of zeroes, as many 4-digit NACE industries contain no HGFs in a given year. Omitting these observations would lead to a truncation problem that risks biasing the results.

Several approaches can be employed to address this problem. One approach would be to transform the dependent variable, e.g., using the formula suggested by Smithson and Verkuilen (2006: 55), allowing $y_{i}^{\prime}=\left(y_{i} *(n-1)+.5\right) / n$, where $\mathrm{n}$ is the sample size; 0 s and 1 s are thereby "pushed" slightly inwards, after which an approach similar to that outlined above can be used. One should, however, be hesitant in adjusting extreme values in a data set if a large percentage can be observed in the extremes.

Preferable to truncation or such censoring is, according to Baum (2008), the approach proposed by Papke and Woolridge (1996), which employs the logit link function (i.e., the logit transformation of the response variable) in conjunction with the binomial distribution. This distribution may be an appropriate choice, even though we are considering a continuous response. The beta distribution must go to zero as the mean goes to either 0 or 1 because the variable approaches a constant in each case. Thus, the variance is maximized for a variable with a mean of 0.5.

In this fractional logit approach, the effective assumption is that 0 s and $1 \mathrm{~s}$ represent very low and very high proportions that "accidentally" result in 
a proportion of 0 or $1{ }^{11}$ We decided to estimate this model using maximum likelihood in a generalized linear model with a logit link. The model only models the conditional mean, which makes it less sensitive to errors in other parts of the model, e.g., the variance. Moreover, this feature makes it less suitable when the researcher's interest is in quantities other than the mean. The model proposed by Papke and Woolridge for the conditional expectation of the fractional response variable is

$$
E\left(y_{i} \mid x_{i}\right)=G\left(x_{i} \boldsymbol{\beta}\right), \quad i=1, \ldots, n
$$

where $0 \leq y_{i} \leq 1$ denotes the dependent variable and the ( $1 * \mathrm{k}$ vector) $\boldsymbol{x}_{\boldsymbol{i}}$ refers to explanatory variables of observation i. The function G(.), which should be a distribution function, is in this case the logistic function, i.e.,

$$
G\left(\boldsymbol{x}_{\boldsymbol{i}} \boldsymbol{\beta}\right)=\frac{\exp \left(\boldsymbol{x}_{\boldsymbol{i}} \boldsymbol{\beta}\right)}{1+\exp \left(\boldsymbol{x}_{\boldsymbol{i}} \boldsymbol{\beta}\right)},
$$

This is estimated using the generalized linear model framework (following McCullagh and Nelder 1989), using the binomial distribution family and hence a Bernoulli log likelihood with the individual contribution given by

$$
l_{i}(\beta)=y_{i} \log \left[G\left(\boldsymbol{x}_{\boldsymbol{i}} \boldsymbol{\beta}\right)\right]+\left(1-y_{i}\right) \log \left[1-G\left(\boldsymbol{x}_{\boldsymbol{i}} \boldsymbol{\beta}\right)\right] .
$$

Inversely, to model the ratio $\mathrm{y}$ as a function of covariates $\mathrm{x}$, we can write

$$
g\left[E\left(y_{i}\right)\right]=\boldsymbol{x}_{\boldsymbol{i}} \boldsymbol{\beta}, \quad y \sim F,
$$

where $\mathrm{g}$ is the link function and $\mathrm{F}$ is the distributional family. In our case, this becomes

$$
\operatorname{logit}\left[E\left(y_{i}\right)\right]=\boldsymbol{x}_{\boldsymbol{i}} \boldsymbol{\beta}, \quad y \sim \text { Bernoulli, }
$$

which should be estimated with robust standard errors. This estimator is $\sqrt{N}$-asymptotically normal regardless of the distribution of $y_{i}$ conditional on $\boldsymbol{x}_{\boldsymbol{i}}$. Post-estimation, we can assess the partial effect of, for example, $x_{1}$ on $E\left(y_{i} \mid \boldsymbol{x}_{\boldsymbol{i}}\right)$ as $\frac{\partial E\left(y_{i} \mid x_{\boldsymbol{i}}\right)}{\partial x_{1}}$ or as $\frac{d G\left(\boldsymbol{x}_{\boldsymbol{i}} \boldsymbol{\beta}\right)}{d x_{1}} \beta_{1}$, where $\frac{d G\left(\boldsymbol{x}_{\boldsymbol{i}} \boldsymbol{\beta}\right)}{d x_{1}}=\frac{\exp \left(\boldsymbol{x}_{\boldsymbol{i}} \boldsymbol{\beta}\right) \text {, }}{\left(1+\exp \left(\boldsymbol{x}_{\boldsymbol{i}} \boldsymbol{\beta}\right)\right)^{2}}$. As this last expression approaches 0 as $x \rightarrow \infty$, the marginal effect goes to 0 as $x_{1}$ becomes large, holding other variables constant (Papke and Woolridge 1996: 627; Oberhofer and Pfaffermayr 2012).

\footnotetext{
${ }^{11}$ An alternative to this approach is to assume that 0 s and $1 \mathrm{~s}$ represent distinct processes that are not generated in the same way as other proportions. This may be the case for some types of proportions, as when city managers make a discrete choice not to spend resources on a certain type of program, giving rise to a sample selection issue. This implies the use of a model such as the zero-one inflated beta model (Cook et al. 2008; Ospina and Ferrari 2012). The choice between the first and second approach rests on assumptions concerning the process generating zeroes or ones. We see no reason to assume different processes and hence choose to not include this approach in the paper. The results obtained when using this model are, however, qualitatively very similar those presented in Tables 2 and 3. They are available from the authors upon request.
} 


\section{Results}

\subsection{Main results}

All results are presented in terms of marginal effects, i.e., the effect of a unit change in the explanatory variable, centered around its mean, on the predicted dependent variable. In our first model specification in Table 2, the main independent variable of interest is the R\&D intensity of industry $i$ at time t-1. In our second specification in Table 3, we replace this with the Eurostat dummies for industries based on whether they are high-tech manufacturing industries or knowledge-intensive service industries, based on Eurostat's classification. All control variables (described in Section 3) are lagged by one period to avoid problems of simultaneity. As mentioned above, the regressions reported in Tables 2 and 3 are performed at the 4digit NACE industry level. ${ }^{12}$

Table 2 presents results of the first model, in which R\&D intensity is the main independent variable of interest. To facilitate the interpretation of the marginal effects, this variable is measured in percentage points, rather than as a share. The coefficient can hence be interpreted as the effect of a percentage point increase in industry $R \& D$ intensity on the share of HGFs. The coefficient for R\&D intensity is always negative and significant in three of four regressions. The results therefore suggest that HGFs are less likely to be observed in industries with high R\&D intensity.

The negative effect is strongest for absolute sales-HGFs. A onepercentage point increase in industry $R \& D$ intensity decreases the expected share of absolute sales-HGFs by 0.0045 . Because the share of HGFs in the overall economy is 0.01 , this latter effect is non-trivial, corresponding to a decrease of 45 percent of the normal share.

The results also indicate that a higher share of HGFs can be found in industries with larger firms. Industries that are dominated by small firms are thus less likely to have a high share of HGFs, suggesting that policies targeting small firm development are not appropriate if policymakers wish to increase the share of fast-growing businesses within industries, which is in line with what has recently been argued by Nightingale and Coad (2014). The share of HGFs also seems to be determined by firm age within the industry, but the direction of the results depends on the choice of growth measure. Industries with older firms have a higher share of HGFs when firm growth is measured in terms of absolute changes but a lower share when growth is measured in relative terms.

${ }^{12}$ A replication of tables 2 and 3 using OLS with robust standard errors yielded very similar results to those reported below. They are available from the authors upon request. 
Table 2. Fractional logit marginal effects. Dependent variable: share of of HGFs in industry at the 4-digit NACE level.

\begin{tabular}{|c|c|c|c|c|}
\hline Share of HGFs in terms of & abs employment & rel employment & abs sales & rel sales \\
\hline \multirow[t]{2}{*}{ R\&D intensity } & -0.0010 & $-0.0011^{*}$ & $-0.0045^{* *}$ & $-0.0016 * * *$ \\
\hline & $(-1.55)$ & $(-1.85)$ & $(-2.06)$ & $(-3.38)$ \\
\hline \multirow[t]{2}{*}{ Mean age } & $0.0009 * * *$ & -0.0001 & $0.0016^{* * *}$ & $-0.0004 * * *$ \\
\hline & $(9.08)$ & $(-1.53)$ & $(14.01)$ & $(-6.91)$ \\
\hline \multirow[t]{2}{*}{ Sd (age) } & 0.0004 & 7.02e-05 & $0.0012 * * *$ & -0.0002 \\
\hline & $(0.95)$ & $(0.18)$ & (2.79) & $(-0.48)$ \\
\hline \multirow[t]{2}{*}{ No of firms } & $-3.82 \mathrm{e}-05 * * *$ & $-5.04 \mathrm{e}-06 * * *$ & $-4.59 \mathrm{e}-05^{* * *}$ & $2.55 \mathrm{e}-06^{* * *}$ \\
\hline & $(-8.84)$ & $(-4.74)$ & $(-7.94)$ & $(3.05)$ \\
\hline \multirow[t]{2}{*}{ No of employees } & $1.48 \mathrm{e}-06^{* * *}$ & $2.78 \mathrm{e}-07 * * *$ & $1.96 \mathrm{e}-06^{* * *}$ & 2.87e-08 \\
\hline & $(14.46)$ & $(5.04)$ & (11.48) & $(0.44)$ \\
\hline \multirow[t]{2}{*}{ Entry } & $8.41 \mathrm{e}-06^{* * *}$ & 6.73e-07 & $5.69 \mathrm{e}-06^{*}$ & $-1.06 \mathrm{e}-06^{* *}$ \\
\hline & (3.58) & $(1.22)$ & $(1.86)$ & $(-2.26)$ \\
\hline \multirow[t]{2}{*}{ Exit } & $0.0005^{* * *}$ & $0.0001 * * *$ & $0.0006 * * *$ & $-3.73 e-05^{*}$ \\
\hline & $(5.27)$ & $(3.67)$ & $(4.35)$ & $(-1.68)$ \\
\hline \multirow[t]{2}{*}{ Concentration } & $0.0258 * * *$ & 0.0013 & $0.0389 * * *$ & $0.0063 * * *$ \\
\hline & $(9.51)$ & $(0.58)$ & $(12.11)$ & $(3.18)$ \\
\hline Observations & 6,637 & 6,637 & 6,637 & 6,637 \\
\hline Log pseudolikelihood & -570.86 & -296.98 & -674.87 & -295.85 \\
\hline AIC & .175 & .092 & .206 & .092 \\
\hline $\mathrm{BIC}$ & -57849.93 & -58072.6 & -57716.85 & -58087.27 \\
\hline
\end{tabular}

The results of the second specification are presented in Table 3. The findings regarding the second hypothesis are inconsistent. When high growth is measured using employment, the high-tech manufacturing dummy is insignificant. In contrast, a high-technology manufacturing industry should exhibit an average share of absolute sales-HGFs that is 0.02 higher than the baseline case. Because the normal share of HGFs is 0.01 , this effectively implies a tripling of the expected share of absolute sales-HGFs relative to the share in the overall population. However, being classified as a high-tech manufacturing industry decreases the expected share of relative sales-HGFs by nearly 0.006. Again, compared with the share of HGFs in the overall population, this negative effect is in the range of 60 percent.

In contrast, we observe that the effect of the knowledge intensive services dummy is positive and significant in three of the four regressions at the 4digit level. The result is most pronounced for absolute employmentHGFs, the expected share of which may be 0.027 higher, suggesting a 
near quadrupling relative to the normal share of 0.01 . We are thus unable to reject hypothesis 3 .

The control variables in the second model exhibit a roughly consistent pattern. First, the age variable has a positive and significant effect on the share of HGFs defined in absolute numbers, whereas this effect is negative and significant when HGFs are defined in relative terms. The standard deviation of age is seldom significant. While the effect of the number of firms in the industry appears ambiguous, HGFs are more common in industries in which the median firm is relatively large. There appears to be little substantial effect of entry and an ambiguous effect of exit. The effects of market concentration and MES on the industry share of HGFs are dependent on the choice of empirical model; hence, these results should be interpreted with caution. Again, however, we observe that the number of employees is positive and significant.

Table 3. Fractional logit marginal effects. Dependent variable: share of of HGFs in industry at the 4-digit NACE level.

\begin{tabular}{lllll}
\hline \hline Share of HGFs in terms of & abs employment & rel employment & abs sales & rel sales \\
\hline \hline high-tech manufacturing & 0.0010 & 0.0077 & $0.0203^{* *}$ & $-0.0063^{* * *}$ \\
& $(0.22)$ & $(1.01)$ & $(2.32)$ & $(-4.67)$ \\
knowledge intensive services & $0.0270^{* * *}$ & $0.0095^{* *}$ & $0.0185^{* * *}$ & 0.0025 \\
& $(5.32)$ & $(2.25)$ & $(3.75)$ & $(1.08)$ \\
Mean age & $0.0009^{* * *}$ & $-9.75 \mathrm{e}-05$ & $0.0016^{* * *}$ & $-0.0004^{* * *}$ \\
& $(9.75)$ & $(-1.23)$ & $(14.40)$ & $(-6.78)$ \\
Sd (age) & 0.0004 & $8.43 \mathrm{e}-05$ & $0.0011^{* * *}$ & -0.0001 \\
& $(1.17)$ & $(0.22)$ & $(2.72)$ & $(-0.37)$ \\
No of firms & $-3.69 \mathrm{e}-05^{* * *}$ & $-4.39 \mathrm{e}-06^{* * *}$ & $-4.23 \mathrm{e}-05^{* * *}$ & $2.84 \mathrm{e}-06^{* * *}$ \\
& $(-8.85)$ & $(-4.09)$ & $(-8.02)$ & $(3.45)$ \\
No of employees & $1.36 \mathrm{e}-06^{* * *}$ & $1.80 \mathrm{e}-07^{* * *}$ & $1.71 \mathrm{e}-06^{* * *}$ & $-4.18 \mathrm{e}-09$ \\
& $(15.82)$ & $(2.74)$ & $(12.81)$ & $(-0.06)$ \\
Entry & $9.08 \mathrm{e}-06^{* * *}$ & $8.07 \mathrm{e}-07$ & $5.08 \mathrm{e}-06^{*}$ & $-9.81 \mathrm{e}-07^{* *}$ \\
& $(4.05)$ & $(1.54)$ & $(1.85)$ & $(-2.05)$ \\
Exit & $0.0005^{* * *}$ & $0.0001^{* * *}$ & $0.0006^{* * *}$ & $-4.09 \mathrm{e}-05^{*}$ \\
AIC & $(4.83)$ & $(3.66)$ & $(4.43)$ & $(-1.83)$ \\
Concentration & $0.0259^{* * *}$ & 0.0012 & $0.0393^{* * *}$ & $0.0066^{* * *}$ \\
\hline \hline Observations & $(9.70)$ & $(0.54)$ & $(12.32)$ & $(3.26)$ \\
\hline \multirow{2}{*}{ Aog pseudolikelihood } & 6,637 & 6,637 & 6,637 & 6,637 \\
& -566.87 & -295.89 & -672.29 & -295.75 \\
& .174 & .092 & .205 & .092 \\
& -57849.12 & -58065.98 & -57713.2 & -58078.67 \\
\hline
\end{tabular}

Note: robust z-statistics in parentheses. $* * * \mathrm{p}<0.01$, ** $\mathrm{p}<0.05$, * $\mathrm{p}<0.1$ 


\subsection{Robustness checks}

We perform a number of robustness checks. In Table 4, specifications (a) and (b) report coefficients for the main variables of interest from regressions at the 5- and 3-digit levels. The results regarding $R \& D$ intensity at the 5- and 3-digit levels are very similar to those presented in Table 2, exhibiting negative coefficients. These findings effectively reject hypothesis 1 . In contrast, the results concerning the high-tech dummy appear to be sensitive to aggregation. When regressions are undertaken at the 5-digit level, the coefficients related to the share of HGFs defined in absolute terms are positive and significant, while those relating to HGFs defined in relative terms are negative and significant. This apparent pattern is however blurred at the 3-digit level, at which the only significant coefficient concerns absolute employment-HGFs and is negative. In view of the ambiguity of these results and because they depend on the aggregation level and measurement methodology, we can neither confirm nor reject hypothesis 2 . The knowledge-intensive services dummy, however, is significant and positive in all regressions at the 5and 3-digit levels, suggesting that this result is not sensitive to aggregation. This lends additional support to the third hypothesis.

In specification (c), we only consider organic growth, i.e., we remove any firm that was subject to a merger or acquisition. The coefficient for R\&D intensity remains negative and significant in three of the four regressions. The results for high-tech manufacturing and knowledge-intensive services are very similar if only organic growth is considered, generating coefficients that are somewhat larger than those reported previously. Ultimately, this finding suggests that the results are not particularly sensitive to the inclusion of mergers and acquisitions.

In specifications (d) and (e), we exclude industries with fewer than 30 employees and 100 employees, respectively, to investigate whether our results are driven by industries with small firms. Now, the coefficient for $\mathrm{R} \& \mathrm{D}$ intensity is only negative and significant when growth is measured in terms of sales. The signs and significances remain essentially unchanged for the high-tech and knowledge-intensive dummies.

Ultimately, the robustness checks in Table 4 lend credence to the results reported in Table 2, enabling us to reject hypothesis 1; hypothesis 2 remains ambiguous, and hypothesis 3 cannot be rejected. 
Table 4. Regressions a) at the 5-digit level, b) 3-digit level, and at the 4-digit level with c) only organic growth, d) only industries with at least 30 employees, and e) only industries with at least 100 employees. Control variables are omitted.

\begin{tabular}{|c|c|c|c|c|c|}
\hline & Share of HGFs in terms of & abs employment & rel employment & abs sales & rel sales \\
\hline \multirow[t]{3}{*}{ a) 5-digit NACE level } & R\&D intensity & $-0.0017^{*}$ & -0.0006 & $-0.0058 * *$ & $-0.0007^{*}$ \\
\hline & & $(-1.84)$ & $(-1.08)$ & $(-2.42)$ & $(-1.84)$ \\
\hline & Observations & 9,265 & 9,265 & 9,265 & 9,265 \\
\hline \multirow[t]{3}{*}{ b) 3-digit NACE level } & R\&D intensity & -0.0003 & -0.0016 & $-0.0048 * * *$ & -0.0011 \\
\hline & & $(-0.33)$ & $(-1.34)$ & $(-3.28)$ & $(-1.49)$ \\
\hline & Observations & 2,717 & 2,717 & 2,717 & 2,717 \\
\hline \multirow[t]{3}{*}{ c) Organic growth only } & $\mathrm{R} \& D$ intensity & -0.0010 & $-0.0012^{*}$ & $-0.00569 * *$ & $-0.0021 * * *$ \\
\hline & & $(-1.52)$ & $(-1.73)$ & $(-2.26)$ & $(-3.42)$ \\
\hline & Observations & 6,605 & 6,605 & 6,605 & 6,605 \\
\hline \multirow[t]{3}{*}{ d) Industries >=30 emp } & $\mathrm{R} \& \mathrm{D}$ intensity & 0.0003 & -0.0007 & $-0.00444^{*}$ & $-0.0009 *$ \\
\hline & & $(0.23)$ & $(-0.98)$ & $(-1.73)$ & $(-1.82)$ \\
\hline & Observations & 5,742 & 5,742 & 5,742 & 5,742 \\
\hline \multirow[t]{3}{*}{ e) Industries $>=100 \mathrm{emp}$} & R\&D intensity & $6.78 \mathrm{e}-05$ & -0.0005 & $-0.00501^{* *}$ & $-0.0008^{*}$ \\
\hline & & $(0.06)$ & $(-0.73)$ & $(-1.98)$ & $(-1.88)$ \\
\hline & Observations & 4,886 & 4,886 & 4,886 & 4,886 \\
\hline \multirow[t]{5}{*}{ a) 5-digit NACE level } & high-tech manufacturing & $0.0085^{* * *}$ & $-0.0022^{*}$ & $0.0145^{* * *}$ & $-0.0036 * * *$ \\
\hline & & $(4.07)$ & $(-1.91)$ & $(5.15)$ & $(-3.96)$ \\
\hline & knowledge intensive services & $0.0059 *$ & $0.0061^{* *}$ & $0.0107 * * *$ & $0.0088^{* * *}$ \\
\hline & & $(1.76)$ & $(2.33)$ & $(2.74)$ & $(3.41)$ \\
\hline & Observations & 9,265 & 9,265 & 9,265 & 9,265 \\
\hline \multirow[t]{5}{*}{ b) 3-digit NACE level } & high-tech manufacturing & $-0.0085 * * *$ & 0.0059 & 0.0055 & 0.0006 \\
\hline & & $(-5.12)$ & $(1.04)$ & $(1.08)$ & $(0.16)$ \\
\hline & knowledge intensive services & $0.0204 * * *$ & $0.0149 * *$ & $0.0232 * * *$ & 0.0038* \\
\hline & & (3.93) & $(2.06)$ & $(4.30)$ & $(1.88)$ \\
\hline & Observations & 2,717 & 2,717 & 2,717 & 2,717 \\
\hline \multirow[t]{5}{*}{ c) Organic growth only } & high-tech manufacturing & -0.0006 & 0.0080 & $0.0330 * * *$ & $-0.0071^{* * *}$ \\
\hline & & $(-0.13)$ & $(0.95)$ & (3.38) & $(-4.77)$ \\
\hline & knowledge intensive services & $0.0337 * * *$ & $0.0112 * *$ & $0.0289 * * *$ & 0.0033 \\
\hline & & $(5.48)$ & $(2.36)$ & $(4.29)$ & $(1.58)$ \\
\hline & Observations & 6,605 & 6,605 & 6,605 & 6,605 \\
\hline \multirow[t]{5}{*}{ d) Industries >=30 emp } & high-tech manufacturing & -0.0018 & 0.0074 & $0.0159 *$ & $-0.0063 * * *$ \\
\hline & & $(-0.40)$ & $(0.96)$ & $(1.85)$ & $(-4.93)$ \\
\hline & knowledge intensive services & $0.0296 * * *$ & $0.0111^{* *}$ & $0.0209 * * *$ & 0.0017 \\
\hline & & $(5.70)$ & $(2.30)$ & $(4.08)$ & $(1.25)$ \\
\hline & Observations & 5,742 & 5,742 & 5,742 & 5,742 \\
\hline \multirow[t]{5}{*}{ e) Industries >=100 emp } & high-tech manufacturing & -0.0036 & 0.0012 & $0.0172 *$ & $-0.0055 * * *$ \\
\hline & & $(-0.77)$ & $(0.33)$ & $(1.85)$ & $(-3.78)$ \\
\hline & knowledge intensive services & $0.0295 * * *$ & $0.0111^{* *}$ & $0.0203 * * *$ & 0.0014 \\
\hline & & $(5.67)$ & $(2.16)$ & (3.94) & (1.33) \\
\hline & Observations & 4,886 & 4,886 & 4,886 & 4,886 \\
\hline
\end{tabular}

Note: Robust z-statistics in parentheses. $* * * \mathrm{p}<0.01, * * \mathrm{p}<0.05, * \mathrm{p}<0.1$ 


\section{Concluding remarks}

Recent studies have demonstrated that a small number of fast-growing firms generate most job creation and economic growth. HGFs have therefore received an increasing amount of attention from both policymakers and researchers. A common policy recommendation is that policymakers should cease supporting new start-ups in general and instead target industrial policies towards potential fast-growing firms. A suggested strategy is to target high-tech industries, i.e., industries with high R\&D intensity. Previous studies have nonetheless indicated that HGFs are not more common in these industries, suggesting that such policies might be ineffective for promoting job growth.

Prior evidence is, however, based on studies that investigated a limited number of industries, excluded small firms, were based on highly aggregated data, and applied cutoff points. We therefore examined the distribution of HGFs across industries, using a comprehensive, firm-level data set comprising all limited liability firms in Sweden during the period 1997-2008. In contrast to previous studies, our analysis covered firms of all sizes and from all industries. We also employed a model capable of employing proportions as the dependent variable. The regressions were estimated at the 3-, 4-, and 5-digit NACE industry levels.

The results were fairly robust and suggested that R\&D intensity has a negative or no effect on the share of HGFs, regardless of how HGFs were defined. This challenges the prevailing view that $R \& D$ is beneficial for high growth. Knowledge-intensive service industries were more likely to exhibit a greater share of HGFs, but the results were ambiguous regarding high-tech manufacturing industries. This finding supports the results of Davidsson and Delmar (2003, 2006), who reported that knowledgeintensive service industries had a higher share of HGFs than other industries in Sweden during the period 1987-1996 and is consistent with previous evidence (Rossi-Hansberg and Wright 2007; Klette and Kortum 2004) identifying human capital, rather than $R \& D$, as the crucial factor to explain the prevalence of fat tails in the growth rate distribution. This suggests that further research should investigate the importance of human capital in fostering HGFs.

As mentioned above, many policies for promoting HGFs are strongly connected to R\&D and high-tech sectors (Coad and Rao 2010; OECD 2010; Mason and Brown 2013). In view of this, the policy implications of our results are troubling because they suggest that the relationship between R\&D and high growth is, at best, highly complex but is most likely negative. While there may be exceptions, the knowledge required for policy-makers to be able to pick winners (whether industries or firms) 
simply does not exist.

Furthermore, a clear link between knowledge-intensive service industries and the share of HGFs does not necessarily justify policy interventions. First, if industries or firms with certain characteristics have a greater propensity to grow, why should they receive assistance? Policy interventions should be based on some type of argument relating to market failure. If no such argument can be identified, targeted policies towards knowledge-intensive industries might be counter-productive because such intervention affects the incentives of entrepreneurs; an extensive targeting of industries or firms may result in more unproductive entrepreneurship as returns to rent-seeking activities increase. Firms may perceive that they are better off from meeting the necessary requirements to apply for government subsidies than producing goods and services demanded by consumers (Baumol 1990).

In addition, even if such policies do have the intended effect of increasing the share of HGFs, it is not clear that this will increase industry growth or economic growth more generally. Notably, while Bos and Stam (2014) find that an increase in the prevalence of gazelles in an industry has a positive effect on industry growth, they find no relationship between overrepresentation of HGFs and industry growth. Other research suggests that a larger number of HGFs is associated with a larger number of firms that experience high levels of decline (Bravo-Biosca 2010; Hölzl 2011). Bos and Stam (2014:164) stress that this means "that overrepresentation of gazelles cannot be used as a signpost for 'picking winners'.

An interesting topic for future research is therefore to further analyze whether policies directed towards innovative firms, or potential fastgrowing firms, actually have the intended effects. This requires an improved understanding of the growth processes of fast-growing firms and how policies influence these processes. It also requires longitudinal data on firm support that allow the construction of control groups of similar firms that have not been supported. These types of studies are essential if we wish to enhance our understanding of whether government policies targeted towards potential HGFs are effective. 


\section{References}

Acs, Z. J. (2009). “Entrepreneurial Capitalism” in capitalist development. Toward a synthesis of capitalist development and the “economy as a whole”, in Z. J. Acs, D. B. Audretsch and R. J. Storm (eds.), Entrepreneurship, Growth and Public Policy. Cambridge University Press: Cambridge.

Acs, Z. J. and Audretsch, D. B. (2005), 'Entrepreneurship, innovation and technological change', Foundation and Trends in Entrepreneurship, 1(4), $1-49$.

Acs, Z. J., Armington, C. and Zhang, T. (2007), 'The determinants of new-firm survival across regional economies: the role of human capital stock and knowledge spillover', Papers in Regional Science, 86, 367391.

Acs, Z. J., Audretsch, D., Braunerhjelm, P. and Carlsson, B. (2004), 'The missing link. The knowledge filter and entrepreneurship in endogenous growth'. CEPR DP 4783. CEPR: London.

Acs, Z. J., Parsons, W. and Tracy, S. (2008), 'High impact firms: gazelles revisited', An Office of Advocacy Working Paper. U.S. Small Business Administration: New York.

Acz, Z., Braunerhjelm, P., Audretsch, D. and Carlsson, B. (2009), 'The Knowledge Spill-Over Theory of Entrepreneurship', Small Business Economics, 32, 15-30.

Aghion, P. and Howitt, P. (1992), 'A model of growth through creative destruction’, Econometrica, 60, 323-351.

Almus, M. (2002), 'What characterizes a fast-growing firm?', Applied Economics, 34(12), 1497-1508.

Almus, M. and Nerlinger, E. A. (1999), 'Growth of new technologybased firms: which factors matter?’, Small Business Economics, 13, 141154.

Anyadike-Danes, M., Bonner, K., Hart, M. and Mason, C. (2009), 'Measuring business growth - High-growth firms and their contribution to employment in the UK'. ERINI, Economic Research Institute of Northern Ireland, Monograph, 44.

Arvanitis, S. and Stucki, T. (2012), 'What determines the innovation capability of firm founders?', Industrial and Corporate Change, 21, 1049-1084. 
Audretsch, D. B. (1995), 'Innovation, growth and survival', International Journal of Industrial Organization, 13, 441-457.

Audretsch, D. B. and Fritsch, M. (2002), 'Growth regimes over time and space', Regional Studies, 36(2), 113-124.

Audretsch, D. B. and Thurik, A. R. (2000), 'Capitalism and democracy in the 21st century: from the managed to the entrepreneurial economy', Journal of Evolutionary Economics, 10(1), 17-34.

Audretsch, D., Keilbach, M. and Lehmann, E. (2006), Entrepreneurship and Economic Growth. Oxford University Press: New York.

Autio, E., Arenius, P. and Wallenius, H. (2000), 'Economic impact of gazelle firms in Finland'. Working Papers Series 2000:3, Helsinki University of Technology, Institute of Strategy and International Business: Helsinki.

Bates, T. (1990), 'Entrepreneur human capital inputs and small business longevity', Review of Economics and Statistics, 72, 551-559.

Baum, C. F. (2008), 'Modelling Proportions', The Stata Journal, 8(2), 299-303.

Baumol, W. J. (1990), 'Entrepreneurship: productive, unproductive and destructive', Journal of Political Economy, 98(5), 893-921.

Baumol, W. J. (2004), 'Entrepreneurial enterprises, large established firms and other components of the free-market growth machine', Small Business Economics, 23(1), 9-21.

Bernstein, J. I. and Mamuneas, T. P. (2006), 'R\&D depreciation, stocks, user costs and productivity growth for US R\&D intensive industries', Structural Change and Economic Dynamics, 17(1), 70-98.

Birch, D. L., and Medoff, J. (1994), 'Gazelles', in L. C. Solmon \& A. R. Levenson (eds), Labor Markets, Employment Policy and Job Creation. Westview: Boulder, CO.

Birch, D. L., Haggerty, A. and Parsons, W. (1995), Who's Creating Jobs? Cognetics Inc: Boston, MA.

Bleda, M., Morrison, K. and Rigby, J. (2013), 'The role and importance of gazelles and other growth firms for innovation and competitiveness', in D. Cox \& J. Rigby (eds), Innovation Policy Challenges for the 21st Century. Routledge: London. 
Bos, J. and E. Stam (2014), 'Gazelles and industry growth: a study of young high-growth firms in the Netherlands', Industrial and Corporate Change, 23(1), 145-169.

Braunerhjelm, P., Acs, Z., Audretsch, D., Braunerhjelm, P. and Carlsson, B. (2010), 'The missing link. Knowledge diffusion and entrepreneurship in endogenous growth', Small Business Economics, 34, 105-125.

Braunerhjelm, P. (2011), 'Entrepreneurship, innovation and economic growth: interdependencies, irregularities and regularities', in D.B. Audretsch, O. Falck, \& S. Heblich, (eds), Handbook of Research on innovation and Entrepreneurship. Edward Elgar Publishing: Norhampton, MA.

Bravo-Biosca, A. (2010), 'Growth dynamics: exploring business growth and contraction in Europe and the US', NESTA Research Report. NESTA: London, UK.

Brown, C., Haltiwanger, J. and Lane, J. (2006), Economic Turbulence - Is a Volatile Economy Good for America? University of Chicago Press: Chicago.

Brown, R., Mason, C. and Mawson, S. (2014), 'Increasing "the vital 6 percent”: designing effective public policy to support high growth firms', NESTA Working Paper No. 14/01. NESTA: London, UK.

Brännback, M., Kiviluoto, N., Carsrud, A. and Östermark, R. (2010), 'Much ado about nearly nothing? An exploratory study on the myth of high growth technology start-up entrepreneurship', Frontiers of Entrepreneurship Research, 30(12), 1-14.

Buss, T. (2002), 'Emerging high growth firms and economic development policy’, Economic Development Quarterly, 16, 17-19.

Calvo, J. L. (2006), 'Testing Gibrat's law for small, young and innovating firms’, Small Business Economics, 26, 117-123.

Cefis, E. and Orsenigo, L. (2001), 'The persistence of innovative activities; a cross country and cross-sectors comparative analysis', Research Policy, 30, 1139-1158.

Cefis, E. and Marsili, O. (2005), 'A matter of life and death: innovation and firm survival', Industrial and Corporate Change, 14, 1167-1192.

Chandler, A. (1990), Scale and scope: The dynamics of industrial capitalism. Harvard University Press: Cambridge, MA. 
Chappell, W. F., Mwangi, S. K. and Walter, J. M. (1990), 'A Poisson probability model of entry and market structure with an application to U.S. industries during 1972-77', Southern Economic Journal, 56, 918927.

Coad, A. (2007), Empirical investigations into the characteristics and determinants of the growth of firms. Doctorat Sciences Economiques, Université Paris 1: Paris, FR.

Coad, A. and Hölzl, W. (2010), 'Firm growth: empirical analysis'. Max Planck Institute of Economics Papers on Economics and Evolution, 1002. Max Planck Institute: Germany.

Coad, A. and Rao, R. (2008), 'Innovation and firm growth in high-tech sectors: a quantile regression approach', Research Policy, 37(4), 633648.

Coad, A. and Rao, R. (2010), 'Firm growth and R\&D expenditure', Economics of Innovation and New Technology, 19(2), 127-145.

Coad, A. and Reid, A. (2012), 'The role of Technology and Technologybased Firms in Economic Development - Rethinking Innovation and Enterprise Policy in Scotland', Technopolis Group: Scotland.

Coad, A., Daunfeldt, S. O., Hölzl, W., Johansson, D. and Nightingale, P. (2014a), 'High-growth firms: introduction to the special section', Industrial and Corporate Change, 23(1), 91-112.

Coad, A., Cowling, M., Nightingale, P., Pellegrino, G., Savona, M. and Siepel, J. (2014b), 'Innovative Firms and Growth'. UK Innovation Survey: UK.

Coad, A., Daunfeldt, S.-O., Johansson, D. and Wennberg, K. (2014c), 'Whom do high-growth firms hire?', Industrial and Corporate Change, 23(1), 293-327.

Cohen, W. M. and Klepper, S. (1992), 'The anatomy of industry R\&D intensity distributions', American Economic Review, 82(4), 773-99.

Cohen, W. and Levinthal, D. (1989), 'Innovation and Learning: The Two Faces of R\&D’, Economic Journal, 99, 569-596.

Colombo, M. G. and Grilli, L. (2005), 'Founders' human capital and the growth of new technology-based firms: a competence-based view', Research Policy, 34, 795-816.

Colombo, M. G. and Grilli, L. (2010), 'On growth drivers of high-tech 
start-ups: exploring the role of founders' human capital and venture capital', Journal of Business Venturing, 25, 610-626.

Cook, D. O., Kieschnick, R. and McCullough, B. D. (2008), 'Regression analysis of proportions in finance with self-selection', Journal of Empirical Finance, 15, 860-867.

Daunfeldt, S. O. and Halvarsson, D. (2014), 'Are high-growth firms onehit wonders? Evidence from Sweden', Small Business Economics (forthcoming).

Daunfeldt, S. O., Elert, N. and Johansson, D. (2014a), 'The economic contribution of high-growth firms: do policy implications depend on the choice of growth indicator?', Journal of Industry, Competition and Trade (forthcoming).

Daunfeldt, S. O., Halvarsson, D. and Johansson, D. (2014b), 'Using the Eurostat-OECD definition of high-growth firms: a cautionary note', Journal of Entrepreneurship and Public Policy (forthcoming).

Davidsson, P., Achtenhagen, L. and Naldi, L. (2010), 'Small firm growth', Foundations and Trends in Entrepreneurship, 6(2), 69-166.

Davidsson, P. and Delmar, F. (2003), 'Hunting for new employment: the role of high growth firms', in D. A. Kirby \& A. Watson (eds), Small Firms and Economic Development in Developed and Transition Economies: A Reader. Ashgate Publishing: Hampshire, UK.

Davidsson, P. and Delmar, F. (2006), 'High-growth firms and their contribution to employment: the case of Sweden', in F. Delmar \& J. Wiklund (eds), Entrepreneurship and the Growth of Firms. Edward Elgar Publishing: Cheltenham, UK.

Delmar, F., Davidsson, P. and Gartner, W. B. (2003), 'Arriving at the high-growth firm', Journal of Business Venturing, 18(2), 189-216.

Denrell, J. and Liu, C. (2012), 'Top performers are not the most impressive when extreme performance indicates unreliability', Proceedings of the National Academy of Sciences USA, 109, 9331-9336.

Deschryvere, M. (2008), 'High growth firms and job creation in Finland'. ETLA Discussion Paper 1144. The Research Institute of the Finnish Economy (ETLA): Helsinki.

de Wit, G. and Timmermans, N. G. L. (2008), 'High-growth SMEs evidence from the Netherlands', EIM Research Reports and 
Publieksrapportages H200818. EIM: Netherlands.

Dosi, G. (2007), 'Statistical regularities in the evolution of industries: a guide through some evidence and challenges for the theory', in F. Malerba \& S. Brusoni (eds), Perspectives on Innovation. Cambridge University Press: Cambridge, UK.

Dunne, P., and Hughes, A. (1994), 'Age, size, growth and survival: UK companies in the 1980s', Journal of Industrial Economics, 42, 115-140.

Eckhardt, J. T. and Shane, S. A. (2011), 'Industry changes in technology and complementary assets and the creation of high-growth firms', Journal of Business Venturing, 26(4), 412-430.

Ejermo O., Kander A., and Svensson Henning, M. (2011), 'The R\&D growth paradox arises in fast-growing sectors', Research Policy, 40, 664672.

Ericson, R. and Pakes, A. (1995), 'Markov-perfect industry dynamics: a framework for empirical work', Review of Economic Studies, 62, 53-82.

Eurostat (2012), 'Knowledge-intensive (business) services in Europe. European Commission'. [Online] Available from: http://ec.europa.eu/research/innovationunion/pdf/knowledge_intensive_business_services_in_europe_2011.pdf. [Accessed: 16 October 2014]

European Commission (2010), 'Europe 2020: a strategy for smart, sustainable and inclusive growth: communication from the commission'. EC Research Report. European Commission: Bruxelles.

Evans, D. S. (1987), 'The relationship between firm growth, size, and age: estimates for 100 manufacturing industries', Journal of Industrial Economics, 35, 567-581.

Fritsch, M. and Mueller, P. (2006), 'The evolution of regional entrepreneurship and growth regimes', in M. Fritsch \& J Schmude (eds), Entrepreneurship in the region. Springer: New York, NY.

Geroski, P. A. (1995), 'What do we know about entry?', International Journal of Industrial Organization, 13, 421-440.

Geroski, P. A., Van Reenen, J. and Walters, C. (1997), 'How persistently do firms innovate?', Research Policy, 26(1), 33-48.

Geroski, P. A., Mata, J., and Portugal, P. (2010), 'Founding conditions and the survival of new firms', Strategic Management Journal, 31, 510- 
529.

Gimeno, J., Folta, T., Cooper, A. and Woo, C. (1997), 'Survival of the fittest? Entrepreneurial human capital and the persistence of underperforming firms', Administrative Science Quarterly, 42, 750-783.

Halabisky, D., Dreessen, E. and Parsley, C. (2006), 'Growth in firms in Canada, 1985-1999', Journal of Small Business and Entrepreneurship, 19(3), 255-268.

Haltiwanger, J., Jarmin, R. S. and Miranda, J. (2013), 'Who creates jobs? Small versus large versus young', Review of Economics and Statistics, 95(2), 347-361.

Hatzichronoglou, T. (1997), 'Revision of the high-technology sector and product classification', OECD Science, Technology and Industry Working Papers, 1997/2. OECD: Geneva.

Hannan, M. T. and Freeman, J. (1977), 'The population ecology of organizations', American Journal of Sociology, 82(5), 929-964.

Henrekson, M. and Johansson, D. (2010), 'Gazelles as job creators: a survey and interpretation of the evidence', Small Business Economics, 35(2), 227-244.

Hopenhayn, H. (1992), 'Entry, exit and firm dynamics in long run equilibrium’, Econometrica, 60, 1127-1150.

Hulten, C. R. (1990), 'The measurement of capital', in E. R. Berndt \& J. E. Triplett (eds), Fifty Years of Economic Measurement, Studies in Income and Wealth, Vol. 54, The National Bureau of Economic Research. University of Chicago Press: Chicago.

Hölzl, W. (2009), 'Is the R\&D behaviour of fast growing SMEs different? Evidence from CIS III data for 16 countries’, Small Business Economics, 33(1), 59-75.

Hölzl, W. (2010), 'The economics of entrepreneurship policy: introduction to the special issue', Journal of Industry, Competition and Trade, 10(3), 187-197.

Hölzl, W. (2011), 'Unternehmenswachstum im internationalen Vergleich’, WIFO Monatsberichte, 84(8), 557-567.

Hölzl, W. (2014), 'Persistence, survival and growth - a closer look at 20 years of high-growth firms in Austria', Industrial and Corporate Change, 23(1), 199-231. 
Jaffe, A. B., Trajtenberg, M. and Henderson, R. (1993), 'Geographic localization of knowledge spillovers as evidenced by patent citations', The Quarterly Journal of Economics, 108(3), 577-598.

Johansson, D. (2005), 'The turnover of firms and industry growth', Small Business Economics, 24(5), 487-495.

Jovanovic, B. (1982), 'Selection and the evolution of industry', Econometrica, 50(3), 649-670.

Jorgenson, D. W. and Griliches, Z. (1969), 'The explanation of productivity change', Review of Economic Studies, 34, 249-283.

Kirchhoff, B. A. (1994), Entrepreneurship and Dynamic Capitalism. Praeger: Westport, CT.

Klepper, S. and Simons, K. L. (2005), 'Industry shakeouts and technological change', International Journal of Industrial Organization, 23(1-2), 23-43.

Klette, T. J. and Griliches, Z. (2000), 'Empirical patterns of firm growth and R\&D investment: a quality ladder model interpretation', Economic Journal, 110(463), 363-387.

Klette, T. J. and Kortum, S. (2004), 'Innovating firms and aggregate innovation', Journal of Political Economy, 112(5), 986-1018.

Krugman, P. (1992), Geography and trade. Boston, MA: MIT Press.

López-Garcia, P. and Puente, S. (2009), 'What makes a high growth firm? A probit analysis using Spanish firm-level data', Documentos de Trabajo 0920, Banco de España.

Lucas, R. E. (1988), 'On the mechanisms of economic development', Journal of Monetary Economics, 22, 3-42.

Malerba, F. and Orsenigo, L. (1995), 'Schumpeterian patterns of innovation’, Cambridge Journal of Economics, 19(1), 47-65.

Mason, C., and Brown, R. C. (2012), 'Technology-based firms in Scotland', Scottish Enterprise, Glasgow. [Online] Available from: http://www.scottish-

enterprise.com/ /media/SE/Resources/Documents/STUV/TechnologyBased-Firms-in-Scotland.pdf. [Accessed: 16 October 2014]

Mason, C. and Brown, R. (2013), 'Creating good public policy to support high-growth firms’, Small Business Economics, 40(2), 211-225. 
McCullagh, P. and Nelder, J. A. (1989), Generalized Linear Models, 2nd edition. Chapman and Hall: New York.

Moretti, E. (2010), 'Local multipliers', American Economic Review Papers and Proceedings, 100, 1-7.

Moretti, E. and Thulin, P. (2012), 'Local multipliers and human capital in the US and Sweden', IFN Working paper 914. Research Institute of Industrial Economics (IFN): Stockholm.

Nesta (2009), 'The vital 6 per cent: how high-growth innovative businesses generate prosperity and jobs'. National Endowment for Science, Technology and the Arts (NESTA): London.

NSF (2010), 'Science and Engineering Indicators 2010. Chapter 4: Research and Development: National Trends and International Linkages'. National Science Foundation. [Online] Available from: http://www.nsf.gov/statistics/seind10/pdf/c04.pdf. [Accessed: 16 October 2014]

Oberhofer, H. and Pfaffermayr, M. (2012), 'Fractional response models a replication exercise of Papke and Woolrdige (1996)', Contemporary Economics, 6(3), 56-64.

OECD (2002), 'Frascati manual: proposed standard practice for surveys on research and experimental development’. OECD Manual: Paris, FR.

OECD (2005), 'Science technology and industry scoreboard 2005'. OECD Publishing: Paris, FR. [Online] Available from: http://www.oecdilibrary.org/docserver/download/9205071e.pdf?expires=1413442906\&id= id\&accname $=$ guest $\&$ checksum $=$ BA808E1E3C014FBA49503836CA0CA E4E. [Accessed: 16 October 2014]

OECD (2010), 'High-growth enterprises: what governments can do to make a difference. OECD Studies on SMEs and Entrepreneurship, OECD Publishing: Paris, FR. [Online] Available from: http://dx.doi.org/10.1787/9789264048782-en. [Accessed: 16 October 2014]

Orr, D. (1974), 'The determinants of entry: a study of the Canadian manufacturing industries'. Review of Economics and Statistics, 61, 58-66.

Ospina, R. and Ferrari, S. (2012), 'A general class of zero-or-one inflated beta regression models’, Computational Statistics and Data Analysis, 56, 1609-1623. 
Pakes, A. and Ericson, R. (1998), 'Empirical implications of alternative models of firm dynamics', Journal of Economic Theory, 79, 1-45.

Papke, L. and Woolridge, J. (1996), 'Econometric methods for fractional response variables with an application to 401 (k) plan participation rates', Journal of Applied Econometrics, 11(6), 619-632.

Rebelo, S. (1991), 'Long-run policy analysis and long-run growth', Journal of Political Economy, 99, 500-521.

Romer, P. (1986), 'Increasing returns and long run growth', Journal of Political Economy, 94, 1002-1037.

Romer, P. (1990), 'Endogenous technological change', Journal of Political Economy, 98, 71-102.

Rossi-Hansberg, E. and Wright, M. (2007), 'Establishment size dynamics in the aggregate economy', American Economic Review, 97(5), 16391666.

Schneider, C. and Veugelers, R. (2010), 'On young highly innovative companies: why they matter and how (not) to policy support them', Industrial and Corporate Change, 19(4), 969-1007.

Schumpeter, J. A. (1934), The Theory of Economic Development. Harvard University Press: Cambridge, MA.

Schumpeter, J. A. (1943), 'Capitalism, Socialism and Democracy. Harper: New York, NY.

Schreyer, P. (2000), 'High-growth firms and employment', Working Papers, 2000/3, OECD Science, Technology and Industry. OECD: Paris.

Segarra, A. and Teruel, M. (2014), 'High-growth firms and innovation: an empirical analysis for Spanish firms', Small Business Economics (forthcoming).

Segerstrom, P. (1995), 'A quality ladders growth model with decreasing returns to R\&D’. Mimeo, Michigan State University.

Shane, S. (2009), 'Why encouraging more people to become entrepreneurs is bad public policy’, Small Business Economics, 33, 141149.

Smithson, M., and Verkuilen, J. (2006), 'A better lemon squeezer? Maximum-likelihood regression with beta-distributed dependent variables', Psychological Methods, 11(1), 54-71. 
Srholec M. and Verspagen, B. (2012). 'The Voyage of the Beagle into innovation: explorations on heterogeneity, selection, and sectors', Industrial and Corporate Change, 21(5), 1221-1253.

Stam, E. and Wennberg, K. (2009), 'The roles of R\&D in new firm growth’, Small Business Economics, 33(1), 77-89.

Stanley, M., Amaral, L., Buldyrev, S., Havlin, S., Leschhorn, H., Maass, P., Salinger, M. and Stanley, H. (1996), 'Scaling behaviour in the growth of companies’, Nature, 379(6568), 804-806.

Storey, D. J. (1991), 'The birth of new firms - does unemployment matter? A review of the evidence', Small Business Economics, 3(3), 167178.

Storey, D. J. (1994), Understanding the Small Business Sector. Routledge: London, UK.

van Ort, F. and Stam, E. (2006), 'Agglomeration economies and entrepreneurship in the ICT industries', ERIM Report Series, 016-ORG. Erasmus University: Rotterdam.

van Stel, A., Carree, M. and Thurik, R. (2005), 'The effect of entrepreneurial activity on national economic growth', Small Business Economics, 24(3), 311-321.

Vivarelli, M. (2013), 'Is entrepreneurship necessarily good? Microeconomic evidence from developed and developing countries', Industrial and Corporate Change, 22 (6), 1453-1495.

Warsh, D. (2006), Knowledge and the Wealth of Nations. W.W. Norton \& Company: New York:

Winter, S. G. (1984), 'Schumpeterian competition in alternative technological regimes', Journal of Economic Behavior and Organization, 5(3-4), 287-320.

Wyrwich, M. (2010), 'Socioeconomic heritage and rapid firm growth'. Jena Economic Research Paper, 2009 - 092. Max Planck: Germany.

Yasuda, T. (2005), 'Firm growth, size, age, and behavior in Japanese manufacturing', Small Business Economics, 24, 1-15. 


\section{Appendix}

Table A1. High-tech manufacturing and knowledge intensive services definition based on NACE rev. 2 classification.

1. High-tech manufacturing industries:

o Manufacture of basic pharmaceutical products and pharmaceutical preparations - division 21

o Manufacture of computers and electronic components (groups 26.1, 26.2)

- Manufacture of electronic components and boards - group 26.1

- Manufacture of computers and peripheral equipment - group 26.2

o Manufacture of consumer electronics and optical instruments (groups 26.3, 26.4, 26.7, 26.8)

- Manufacture of communication equipment - group 26.3

- Manufacture of consumer electronics - group 26.4

- Manufacture of optical instruments and photographic equipment - group 26.7

- Manufacture of magnetic and optical media - group 26.8

o Manufacture of measuring, testing, navigation and medical instruments (groups 26.5, 26.6)

- Manufacture of instruments and appliances for measuring, testing and navigation; watches and clocks - group 26.5

- Manufacture of irradiation, electromedical and electrotherapeutic equipment - group 26.6

o Manufacture of air and spacecraft and related machinery - group 30.3

2. Knowledge intensive services industries:

o Audiovisual and information activities (divisions 59, 60, 63)

- Motion picture, video and television program production, sound recording and music publishing activities - division 59

- Programming and broadcasting activities - division 60

- Information service activities - division 63

o ICT-related activities (divisions 61, 62)

- Telecommunications - division 61

- Computer programming, consultancy and related activities - division 62

o Scientific research and development (division 72)

- Research and experimental development on natural sciences and engineering - group 72.1

- Research and experimental development on social sciences and humanities - group 72.2 


\begin{tabular}{|c|c|c|c|c|c|c|}
\hline & HGFs defined in terms of & $\begin{array}{c}\text { Absolute } \\
\text { employme } \\
\text { nt }\end{array}$ & $\begin{array}{c}\text { Relative } \\
\text { employme } \\
\text { nt } \\
\end{array}$ & $\begin{array}{c}\text { Absolute } \\
\text { sales }\end{array}$ & $\begin{array}{c}\text { Relative } \\
\text { sales }\end{array}$ & $\begin{array}{l}\text { Number of } \\
\text { firms }\end{array}$ \\
\hline NACE & Industry & share & share & share & share & mean \\
\hline 1 & Agriculture, hunting & 0.001 & 0.005 & 0.001 & 0.009 & 1451.6 \\
\hline 2 & Forestry, logging & 0.002 & 0.006 & 0.008 & 0.013 & 642.2 \\
\hline 3 & Fishing and aquaculture & 0.000 & 0.000 & 0.000 & 0.000 & 26.7 \\
\hline 5 & Mining of coal and lignite & 0.000 & 0.000 & 0.000 & 0.002 & 49.0 \\
\hline 7 & Mining of metal ores & 0.000 & 0.000 & 0.000 & 0.000 & 3.7 \\
\hline 8 & Other mining, quarrying & 0.008 & 0.005 & 0.008 & 0.004 & 55.7 \\
\hline 9 & Mining support service activities & 0.000 & 0.000 & 0.000 & 0.250 & 0.9 \\
\hline 10 & Manu: food & 0.025 & 0.021 & 0.026 & 0.004 & 216.4 \\
\hline 11 & Manu: beverages & 0.071 & 0.000 & 0.077 & 0.019 & 9.4 \\
\hline 12 & Manu: tobacco & 0.000 & 0.000 & 0.000 & 0.000 & 0.8 \\
\hline 13 & Manu: textiles & 0.022 & 0.004 & 0.024 & 0.000 & 65.9 \\
\hline 14 & Manu: wearing apparel & 0.002 & 0.004 & 0.010 & 0.008 & 151.6 \\
\hline 15 & Manu: leather & 0.025 & 0.006 & 0.022 & 0.006 & 556.3 \\
\hline 16 & Manu: wood & 0.015 & 0.004 & 0.019 & 0.008 & 295.3 \\
\hline 17 & Manu:paper & 0.009 & 0.005 & 0.016 & 0.003 & 251.9 \\
\hline 18 & Manu: printing, recordings & 0.008 & 0.003 & 0.004 & 0.001 & 332.3 \\
\hline 19 & Manu: coke, refined petroleum & 0.009 & 0.014 & 0.027 & 0.009 & 61.7 \\
\hline 20 & Manu: chemicals & 0.019 & 0.008 & 0.024 & 0.008 & 864.2 \\
\hline 21 & Manu: pharmaceutical & 0.043 & 0.015 & 0.113 & 0.006 & 153.3 \\
\hline 22 & Manu: rubber, plastic & 0.010 & 0.009 & 0.007 & 0.007 & 1567.4 \\
\hline 23 & Manu: other non-metallic mineral & 0.035 & 0.009 & 0.078 & 0.005 & 95.9 \\
\hline 24 & Manu: basic metals & 0.048 & 0.008 & 0.075 & 0.004 & 268.4 \\
\hline 25 & Manu: fabricated metal, not machinery & 0.015 & 0.005 & 0.012 & 0.003 & 1163.4 \\
\hline 26 & Manu: computers, electronic, optical & 0.025 & 0.013 & 0.028 & 0.007 & 353.4 \\
\hline 27 & Manu: electrical equipment & 0.046 & 0.006 & 0.066 & 0.005 & 224.0 \\
\hline 28 & Manu: machinery, equipment & 0.015 & 0.007 & 0.011 & 0.004 & 2251.3 \\
\hline 29 & Manu: motor vehicles & 0.033 & 0.008 & 0.029 & 0.007 & 1191.8 \\
\hline 30 & Manu: other transport & 0.030 & 0.009 & 0.037 & 0.004 & 139.6 \\
\hline 31 & Manu: furniture & 0.030 & 0.013 & 0.025 & 0.007 & 427.8 \\
\hline 32 & Manu: other manufacturing & 0.010 & 0.010 & 0.007 & 0.006 & 1399.0 \\
\hline 33 & Manu: repair installation machinery & 0.015 & 0.007 & 0.016 & 0.006 & 645.6 \\
\hline 35 & Electricity, gas, steam, hot water supply & 0.031 & 0.013 & 0.037 & 0.008 & 276.0 \\
\hline 36 & Water collection, treatment, supply & 0.014 & 0.008 & 0.008 & 0.009 & 376.4 \\
\hline 37 & Sewerage & 0.021 & 0.025 & 0.029 & 0.009 & 41.6 \\
\hline 38 & Waste collection & 0.025 & 0.010 & 0.022 & 0.007 & 49.6 \\
\hline 41 & Construction of buildings & 0.009 & 0.009 & 0.009 & 0.007 & 571.3 \\
\hline 42 & Civil engineering & 0.012 & 0.000 & 0.026 & 0.000 & 36.4 \\
\hline 43 & Specialized construction activities & 0.003 & 0.007 & 0.002 & 0.005 & 1946.6 \\
\hline 45 & Wholesale retail repair of motor vehicles & 0.006 & 0.009 & 0.005 & 0.005 & 6617.7 \\
\hline 46 & Wholesale trade except motor vehicles & 0.009 & 0.007 & 0.019 & 0.009 & 2506.0 \\
\hline 47 & Retail trade except motor vehicles & 0.005 & 0.005 & 0.004 & 0.005 & 2015.9 \\
\hline 49 & Land transport; transport via pipelines & 0.010 & 0.009 & 0.005 & 0.004 & 1102.9 \\
\hline 50 & Water transport & 0.009 & 0.008 & 0.014 & 0.008 & 2988.8 \\
\hline 51 & Air transport & 0.009 & 0.010 & 0.014 & 0.010 & 8172.0 \\
\hline 52 & Warehouse, support for transport & 0.006 & 0.007 & 0.005 & 0.007 & 6719.1 \\
\hline 53 & Postal and courier activities & 0.371 & 0.043 & 0.225 & 0.030 & 3.9 \\
\hline
\end{tabular}




\begin{tabular}{|c|c|c|c|c|c|c|}
\hline & HGFs defined in terms of & $\begin{array}{c}\text { Absolute } \\
\text { employme } \\
n t\end{array}$ & $\begin{array}{c}\text { Relative } \\
\text { employme } \\
\text { nt } \\
\end{array}$ & $\begin{array}{c}\text { Absolute } \\
\text { sales }\end{array}$ & $\begin{array}{c}\text { Relative } \\
\text { sales }\end{array}$ & $\begin{array}{l}\text { Number of } \\
\text { firms }\end{array}$ \\
\hline 53 & Postal and courier activities & 0.371 & 0.043 & 0.225 & 0.030 & 3.9 \\
\hline 55 & Accommodation & 0.008 & 0.014 & 0.002 & 0.009 & 1790.0 \\
\hline 56 & Food and beverage service & 0.006 & 0.016 & 0.003 & 0.009 & 339.9 \\
\hline 58 & Publishing activities & 0.023 & 0.012 & 0.019 & 0.008 & 224.9 \\
\hline 59 & Motion picture, video, tv production & 0.006 & 0.009 & 0.011 & 0.008 & 146.3 \\
\hline 60 & Programming, broadcasting & 0.009 & 0.012 & 0.005 & 0.006 & 3059.0 \\
\hline 61 & Telecommunications & 0.034 & 0.016 & 0.057 & 0.009 & 191.1 \\
\hline 62 & Computer programming & 0.024 & 0.018 & 0.016 & 0.018 & 400.1 \\
\hline 63 & Information service & 0.028 & 0.018 & 0.030 & 0.012 & 758.7 \\
\hline 64 & Financial services, except insurance, pension & 0.013 & 0.020 & 0.029 & 0.031 & 488.6 \\
\hline 65 & Insurance, pension, not social security & 0.021 & 0.028 & 0.048 & 0.040 & 527.7 \\
\hline 66 & Activities auxiliary to finance & 0.000 & 0.010 & 0.005 & 0.037 & 296.9 \\
\hline 68 & Real estate activities & 0.003 & 0.008 & 0.004 & 0.012 & 2087.1 \\
\hline 69 & Legal, accounting activities & 0.003 & 0.003 & 0.002 & 0.012 & 828.9 \\
\hline 70 & Management consultancy & 0.005 & 0.012 & 0.006 & 0.013 & 6428.1 \\
\hline 71 & Architect, technical consultancy & 0.006 & 0.009 & 0.004 & 0.013 & 1914.9 \\
\hline 72 & Scientific research and development & 0.021 & 0.017 & 0.012 & 0.017 & 1796.7 \\
\hline 73 & Advertising, market research & 0.010 & 0.009 & 0.008 & 0.015 & 639.2 \\
\hline 74 & Other professional, scientific, technical & 0.010 & 0.012 & 0.006 & 0.017 & 12037.7 \\
\hline 75 & Veterinary activities & 0.016 & 0.000 & 0.000 & 0.014 & 27.6 \\
\hline 77 & Rental, leasing activities & 0.004 & 0.007 & 0.003 & 0.014 & 250.9 \\
\hline 78 & Employment activities & 0.010 & 0.033 & 0.000 & 0.037 & 21.4 \\
\hline 79 & Travel agency, tour operator & 0.029 & 0.013 & 0.050 & 0.003 & 88.6 \\
\hline 80 & Security, investigation activities & 0.009 & 0.013 & 0.003 & 0.010 & 436.8 \\
\hline 81 & Services buildings, landscape & 0.026 & 0.022 & 0.003 & 0.005 & 191.3 \\
\hline 82 & Office administrative, support & 0.024 & 0.007 & 0.016 & 0.014 & 72.9 \\
\hline 85 & Education & 0.007 & 0.009 & 0.002 & 0.009 & 1829.3 \\
\hline 86 & Human health activities & 0.006 & 0.004 & 0.001 & 0.006 & 435.7 \\
\hline 87 & Residential care & 0.015 & 0.006 & 0.000 & 0.003 & 38.1 \\
\hline 88 & Social work & 0.000 & 0.048 & 0.000 & 0.056 & 6.1 \\
\hline 90 & Creative, arts, entertainment & 0.014 & 0.008 & 0.013 & 0.008 & 264.6 \\
\hline 91 & Libraries, archives, museum & 0.012 & 0.005 & 0.005 & 0.002 & 109.3 \\
\hline 92 & Gambling, betting & 0.008 & 0.010 & 0.005 & 0.011 & 1117.1 \\
\hline 93 & Sports, amusement, recreation & 0.004 & 0.008 & 0.001 & 0.006 & 713.6 \\
\hline 94 & Activities of membership organizations & 0.003 & 0.004 & 0.000 & 0.009 & 35.3 \\
\hline 95 & Repair computers, hous ehold goods & 0.000 & 0.000 & 0.000 & 0.004 & 57.2 \\
\hline 96 & Other service activities & 0.001 & 0.004 & 0.000 & 0.008 & 159.3 \\
\hline
\end{tabular}

